\title{
Urgency of Establishment of Agrarian Court in Indonesia
}

\author{
Nugraha Pranadita ${ }^{1}$ \\ \{nugrahapranadita@uninus.ac.id ${ }^{1}$ \} \\ ${ }^{1}$ Master of Law Studies Program Post-Graduate School, Nusantara Islamic University, \\ Bandung, Indonesia
}

\begin{abstract}
Agrarian disputes are a large part of civil disputes in Indonesia. Agrarian disputes are closely related to people's welfare, legal certainty is needed in terms of their settlement. Indonesia as a legal state where the legal objective is to create public welfare has an obligation to conduct an efficient, effective and integrated trial in a national justice system. Through this research, it is expected to illustrate the importance of the existence of an agrarian court, and its position in the judiciary in Indonesia. Thus the conclusions of this study are; (1) based on the description above it can be concluded that the establishment of an agrarian court is important for resolving agrarian disputes which constitute a large part of civil disputes in Indonesia, (2) an agrarian court is a special court that is part of the District Court (3) an agrarian court is a combination of three court functions (civil, criminal, and state administration) specifically related to agrarian issues, and (4) the concept of an agrarian court is in accordance with the concept of a court in the khilafah (Islamic culture) which is part of the mainstream of world culture.
\end{abstract}

Keywords: disputes, agrarian, court, and law

\section{INTRODUCTION}

At the current Directory of Decisions of the Supreme Court of the Republic of Indonesia, there are 23,440 civil decisions, consisting of [1]; (1) 411 divorce dispute decisions, (2) 10.115 land dispute decisions, (3) 115 decisions on property distribution disputes, (4) 1,203 treaty dispute decisions, (5) 1,668 decisions on default disputes, (6) 8,110 unlawful acts, (7) 13 petition decisions, and (8) 1,805 inheritance dispute decisions. Of the total civil court verdicts, 10,115 decisions (43\%) included decisions related to land disputes. According to Sarah D.L. RoeRoe [2]; "Land disputes cannot be avoided today, this is because various land requirements are very high today, while the number of land parcels is limited". Meanwhile, according to the National Land Agency, there are several factors that are the cause of land disputes, namely [3]; (1) limited land supply, (2) inequality in land tenure structures, (3) abandoned land and economic recession, (4) land legal pluralism, (5) community legal perceptions and awareness, (6) government policy inconsistencies, (7) land reform, (8) negligence of land officials, (9) weak land administration system, and (10) neglect of land assets of government agencies. Thus it can be understood that land disputes occupy the largest 
number of civil disputes in Indonesia. That according to Herlina Ratna Sambawa Ningrum[4]; "Land disputes and agrarian sources generally seem to be a latent conflict".

According to Aloysius R. Either; "In the practice of the rule of law, the idea of the state began to become popular in the 17th century, as a result of the socio-political situation in Europe"[5]. Indonesia is a state of law [6], in the constitution of the Republic of Indonesia of the United States of 1949 and the Provisional Constitution of 1950 also stated clearly that Indonesia is a rule of law [7]. The purpose of law in Indonesia is the same and must be the same as the objective of the establishment of the Indonesian government itself, namely [8]; (1) protect the entire Indonesian people, (2) protect all Indonesian bloodshed, (3) promote public welfare, (4) educate the nation's life, and (5) participate in carrying out world order. In state science there are three theories of state goals, namely [9]; (1) the purpose of the state relates to the ultimate goal of man, (2) the purpose of power, and (3) the purpose of prosperity. In this case, protecting all the Indonesian people and the entire bloodshed of Indonesia has conformity with the objectives of power according to the theory of the state's goals. The aim of the state to advance public welfare and educate the life of the nation has conformity with the goals of welfare according to the theory of state goals. While the aim of the state to participate in carrying out world order has conformity with the ultimate goal of man according to the theory of state goals. Based on this, it can be seen that the purpose of the formation of the Indonesian government and/or the purpose of law in Indonesia is in accordance with the theory of state objectives.

The purpose of the law "to protect all the bloodshed of Indonesia" has conformity with Article 33 paragraph (3) of the 1945 Constitution of the Republic of Indonesia, namely; "Earth and water and the natural wealth contained therein are controlled by the state and are used for the greatest possible prosperity of the people". Bloodshed is related to "place (area) of birth" [10], namely land or earth where the Indonesian people are born. About why land or earth needs to be protected because the land or earth is basically controlled by the state. Regarding what the land or earth needs to be controlled by the state so that it can be used for the greatest prosperity of the Indonesian people themselves. Against land or earth, it is possible for two forms of mastery, namely "controlled" by the state and "owned" by individuals (society). "Mastered" and "owned" are two different things, "mastered" related to ability or authority [11], while "owned" is related to ownership [12]. Based on the description, it can be concluded that the land in Indonesia can be the property of the people of Indonesia, but still under the authority of the government, in this case, the government has the ability to regulate the use of the land. This is because land in addition to having an economic function also has a social function [13], namely for the prosperity of the Indonesian people in general. In the end, the regulation of land functions can be seen as a way to advance public welfare which is the goal of law in Indonesia. This can be done if the "control" rights held by the government over the land are higher than the "ownership" rights held by the community towards the land in question.

Regarding the issue of land (agrarian) in Indonesia, the main regulation is contained in the Law of the Republic of Indonesia Number 5 of 1960 concerning Basic Regulations on Agrarian Principles. The law was made with the awareness that at that time the law governing agrarian in Indonesia was dualism, namely using customary law and western law that did not provide legal certainty to the community. With the existence of the law, national agrarian law in Indonesia is then based on customary law and religious law in the hope that it can realize the ideals of the Indonesian nation itself. Although disputes related to agrarian issues are generally included in civil disputes, in fact, there are provisions in the Basic Agrarian Law 
regarding criminal sanctions. Thus agrarian disputes can be part of civil disputes and criminal violations, they can even be part of State Administrative disputes.

\section{METHOD}

This study is normative legal research [14][15] using a conceptual approach. Soerjono Soekanto and Sri Mamuji said that normative juridical research (law) is "legal research conducted by examining library materials or mere secondary data" [16][17]. The data used in this study is secondary data which is then used as primary legal material, secondary legal material, and tertiary legal material. The truth used in normative legal research is a pragmatic truth where something is considered true if it can be verified.

\section{RESULT AND DISCUSSION}

Industrial relations disputes may be resolved by a special court because there are large numbers and have special procedures to deal with disputes as determined by legislation. Bankruptcy and Intellectual Property disputes may be resolved by a special court because of the complexity of the case that requires special expertise and the existence of special procedures to deal with the dispute as determined by legislation. Enrico Simanjuntak believes that; "The liquidation of the jurisdiction's authority that resolves land issues makes land issues a legal gray area, as can be seen from the problematic relationship between administrative law especially with civil law in resolving land issues" [18].

In fact, agrarian disputes are also disputes which, according to researchers/writers, are disputes that are specific because they have multi-dimensions, namely; (1) civil, (2) criminal, and (3) State Administration. There are three absolute jurisdictions of the court that can handle this agrarian dispute, namely; (1) Civil Courts that are part of the General / District Courts, (2) Criminal Courts that are part of the General / District Courts, and (2) State Administrative Courts.

According to Panget [19]; "Land disputes are differences in values, interests, opinions, and perceptions between individuals and between legal entities (private and public) regarding ownership status and or ownership status and or status of use or utilization of certain parcels of land by certain parties, or the status of Tata decisions The State Business concerns the control, ownership, and use or utilization of certain parcels of land.

Judiciary in Indonesia is held by a judicial authority carried out by a Supreme Court and the judicial bodies which are under it [20], namely; (1) general justice, (2) religious justice, (3) military justice, and (4) state administrative court, and there is also the Constitutional Court, a court that is specifically dealing with disputes related to constitutions and electoral disputes. It is also possible for a special court within the court to be under the Supreme Court [21]. Special courts in the District Court, namely; (1) the Human Rights Court is based on the Law of the Republic of Indonesia Number 26 of 2000 concerning the Court of Human Rights, (2) the Industrial Relations Court is based on the Law of the Republic of Indonesia Number 2 of 2004 concerning the Settlement of Industrial Relations Disputes, (3) the Fisheries Court is based on the Law of the Republic of Indonesia Number 31 of 2004 concerning Fisheries, (4) the Commercial Court is based on the Law of the Republic of Indonesia Number 37 of 2004 concerning Bankruptcy and Delay of Obligation to Pay Debt. (5) shipping Court based on the Law of the Republic of Indonesia Number 17 of 2008 concerning Shipping, (6) the Corruption Court is based on the Law of the Republic of Indonesia Number 46 of 2009 
concerning the Corruption Court, and (8) children's Court based on the Republic of Indonesia Law Number 11 of 2012 concerning the Child Criminal Justice System.

Based on the description above, it can be seen that the agrarian problem is the authority of two judicial bodies, namely; (1) general justice, and (2) state administrative court.

In practice, the Land Office / National Land Agency may be involved in an agrarian dispute in the District Court (civil dispute) as a Defendant Party. This is certainly a problem for the Land Office / National Land Agency because it will increase the workload of the personnel (must attend/attend the trial) where the increase in workload may not be directly related to the main task. For the community, agrarian disputes can be seen as a dispute that is very likely to require a lot of time, money and labor, especially if it turns out that for one case of an agrarian dispute, the community must resolve it through several courts.

In Indonesia, a court has specifically been formed specifically related to agrarian issues, namely the Land Reform Court based on the Law of the Republic of Indonesia Number 21 of 1964 concerning the Land Reform Court which was subsequently abolished by the Law of the Republic of Indonesia Number 7 of 1970 concerning the Elimination of the Land Court. applies based on the Law of the Republic of Indonesia Number 6 of 1969 concerning Statements of Invalidity of Various Laws and Government Regulations Substituting Laws. What's interesting about the formation of a Land Reform Court is the definition of the land reform case itself, namely [22]; "... civil, criminal and administrative matters that arise in implementing land reform regulations. (2) What is meant by land reform regulations are: a. Law No. 5 of 1960 concerning Basic Agrarian Principles ... ".

As previously stated, agrarian disputes are special disputes because they have multidimensions, namely; civil, criminal and state administration. This has a correlation with the definition of land reform cases that have multi-dimensions as well, namely; civil, criminal, and administrative. What is different here is between the dispute (case) of state administration and administration. At the time of the enactment of the land reform court law in 1964, there was no State Administrative Court in Indonesia, because the new State Administrative Court existed in 1986 based on the Law of the Republic of Indonesia Number 5 of 1986 concerning the State Administrative Court. Therefore, what is meant by administrative matters in the land reform court law is related to the existence of maladministration carried out by the respondent related to the agrarian problem. Regarding the case of maladministration, the sanctions are of course administrative in nature, such as; reprimand, warning, postponement of promotion, rank/position, and so on. The definition of maladministration is [23]; "Behavior or unlawful conduct, exceeds authority, uses authority for other purposes than that which is intended by the authority, including negligence or neglect of legal obligations in the implementation of public services carried out by State Administrators and governments which cause material losses and/or immateriality to the community and individual ".

According to Nurjannah; "Land reform is interpreted as a change in the ownership structure of land ownership" [24]. At the time of the enactment of the land reform law, one of the judicial instruments (member judges) came from officials from the agrarian department. Thus (officials) the agrarian department acts simultaneously as a regulator and administrator. This certainly makes it difficult for the position of the official of the agrarian department to be able to act neutral (impartially) if the case he is handling is related to the decision of an agrarian official. This is one of the opportunities for legal uncertainty to arise which is very likely to be detrimental to society. Meanwhile, three other member judges from mass peasant organizations [25] are very likely not to have the expertise as a "judge", and it is very likely that the decision will favor the "interests of the peasants". This can also lead to legal uncertainty for business people (investors) in fields related to agrarian issues. Looking at the 
composition of the landform court judges which consists of one career (chairman) judge, one agrarian department official and three representatives from farmer organizations, then the interests of entrepreneurs (investors) will be difficult to be protected because they do not have "representatives" in the panel of judges. Based on the composition of the panel of judges as such it would be difficult for the relevant businessmen (investors) to hope to obtain justice.

Apart from the Basic Agrarian Law, land reform regulations handled by land reform courts include [26]; "B. Law No. 2 of 1960 concerning Production Sharing Agreements (Statutes of 1960 No. 2); c. Law No. 38 Prp. In 1960 concerning the Use and Determination of Land Area for certain plants (Statutes of 1960 No. 120) and their changes and additions; d. Law No. 51 Prp. in 1960 concerning the prohibition on the use of land without permission which was entitled or authorized (Statute Book 1960 No. 158); e. Law No. 56 Prp. 1960 concerning Determination of Agricultural Land Area (Statutes of 1960 No. 174); f. Government Regulation No. 224 of 1961 concerning the Implementation of Land Distribution and Granting of Compensation (Statutes in 1961 No. 280); g. Law No. 16 of 1964 concerning Fishery Products Sharing (Statute Book of 1964 No. 97) insofar as regarding violations of criminal provisions concerned with profit sharing for ponds; h. Other Government Regulations which are the implementation of regulations referred to in letters a to letter g above; "Other regulations explicitly referred to as Landform regulations." The legislation in question is directly related to the welfare of the community. If the existence of an interest in the welfare of the community cannot obtain legal certainty, then it can be ensured that the welfare of the community will become uncertain.

That it is true that in the end the land reform court was abolished based on the Law of the Republic of Indonesia Number 7 of 1970 concerning the Elimination of the Land Reform Court. Nevertheless, the abolition of the land reform court is solely due to three things, namely; (1) "... 3 (three) Representatives of the Peasant Mass Organization who sit as Member Judges to reflect the national unity with a nasakom post is contrary to the Provisional Decree of the People's Consultative Assembly No. XXV/MPRS/1966 and No. XXXVIII/MPRS/1968" [27], (2)" ... the implementation of judicial proceedings in Landreform cases by the Landreform Court has difficulties and bottlenecks" [28], and (3)" ... in fact civil and criminal justice cases, including land reform cases, generally are the authority of the Court -judice in the General Justice environment" [29]. Based on this, the abolition of the land reform court was not caused because the court was not needed to settle land reform cases, but rather because of political factors (related to MPRS Tap), and technical factors (land reform courts were jammed, and overlapping court authority). During the leadership of President Joko Widodo in 2014-2019, there were two programs that supported land reform in Indonesia, namely [30]; (1) "The Ministry of Agrarian and Spatial Planning issues ATR Minister Regulation No. 18 of 2016. Article 3 of the regulation stipulates restrictions on ownership of agricultural land for individuals ", and (2) on 14-18 April 2016, a Multilateral Meeting at Bappenas was held, which produced a program" National Priority for Agrarian Reform ".

Land disputes in Indonesia cannot be resolved thoroughly and optimally through the general court and the state administrative court [31]. The fact that the dispute (case) is related to the agrarian problem is still very much, then the urgency of the establishment of an agrarian court needs to be reconsidered to overcome it. What needs to be considered is that the format of the agrarian court must be able to accommodate objections to the existence of land reform courts that have caused the land reform court to be abolished. Some things that should receive special attention in the formation of the agrarian court are as follows; (1) the position of the Agrarian Court must be a part (specificity) of a public court, namely a special court within the district court. Thus using the procedural law as used in the state court, (2) the judge consists of 
career judges and ad hoc judges as well as the Industrial Relations Court, and (3) the scope of their duties includes the authority to examine and decide on cases of agrarian civil, agrarian criminal, and agrarian state administration.

If one agrarian case includes a civil, criminal case and state administrative case together, then the technical implementation of the trial certainly cannot be combined because each case has a different procedural law. In this case, the examination of the case is still carried out in three different trials, but the judges of the three agrarian-related trials are the same, the proceedings are carried out consecutively, and some parties in the trial are the same. The technical advantages of such trials include; (1) time efficiency because the trial can be conducted on the same day as the same panel of judges, (2) clarity of position cases. It can be assumed that the case of an agrarian civil position, agrarian crime and agrarian State Administration will be related to one another. If the three cases are examined at the same time as the same assembly and the parties are almost the same, then it can be ascertained that the case of the agrarian case position will be built more clearly and more intact, (3) the existence of legal certainty. The implementation of such a trial will allow the panel of judges to have a complete picture regarding the agrarian case in question. If the panel of judges has a complete picture of the case they are handling, then the hope of the judges' decision will be to fulfill a sense of justice and guarantee legal certainty, and (4) the simplicity of the judicial process as a whole so that the process is fast and inexpensive.

\section{CONCLUSIONS}

The establishment of an agrarian court is important for resolving agrarian disputes which are a large part of civil disputes in Indonesia because an agrarian court is a special court that is part of the District Court (general court) which combines three special court functions (civil, criminal, and administrative) related to agrarian problems. The concept of the agrarian court also has conformity with the concept of the court in the Khilafah state (Islamic culture) which is part of the mainstream of world culture.

\section{REFERENCES}

[1] Mahkamah Agung Republik Indonesia, Direktori Putusan, Perdata, Retrieved April 18, 2019 from https://putusan.mahkamahagung.go.id/pengadilan/mahkamahagung/direktori/perdata

[2] Sarah D.L. Roeroe, Penegakan Hukum Agraria Dan Penyelesaian Sengketa Pertanahan Dalam Proses Peradilan, Jurnal Penegakan Hukum, Vol. I, No. 6, Oktober-Desember, Edisi Khusus, p. 100, 2013

[3] Layyin Mahfiana, Sengketa Kepemilikan Hak Atas Tanah Di Kabupaten Ponorogo, Jurnal Kodifikasia, Vol. 7, No. 1, pp. 84-85, 2013

[4] Herlina Ratna Sambawa Ningrum, Analisis Hukum Sistem Penyelesaian Sengketa Atas Tanah Berbasis Keadilan, Jurnal Pembaharuan Hukum, Vol. I, No. 2, p. 221, 2014

[5] Aloysius R. Entah, Indonesia: Negara Hukum yang Berdasarkan Pancasila, Seminar Nasional Hukum, Vol. 2, No. 1, p. 534, 2016

[6] Undang-Undang Dasar Negara Republik Indonesia Tahun 1945, Pasal 1 ayat (3)

[7] Haposan Siallagan, Penerapan Prinsip Negara Hukum Di Indonesia, Jurnal Sosiohumaniora, Vol. 18, No. 2, p. 135, 2016

[8] Undang-Undang Dasar Republik Indonesia Tahun 1945, Pembukaan aline Ke-Empat

[9] Maleha Soemarsono, Negara Hukum Indonesai Ditimjau Dari Sudut Teori Tujuan Negara, Jurnal Hukum dan Pembangunan Tahun Ke-3, 7 (2), pp. 301-302, 2007 
[10] KBBI online, Tumpah Darah, Retrieved April 18, 2019 from https://kbbi.kemdikbud.go.id/entri/tumpah\%20darah

[11] KBBI online, Kuasa, Retrieved April 18, 2019 from https://kbbi.kemdikbud.go.id/entri/kuasa

[12] KBBI online, Milik, Retrieved April 18, 2019 from https://kbbi.kemdikbud.go.id/entri/milik

[13] Undang-Undang Republik Indonesia Nomor 5 Tahun 1960 Tentang Peraturan Dasar Pokok-Pokok Agraria, Pasal 6

[14] Soerjono Soekanto dikutif dari Bambang Sunggono, Metodologi Penelitian Hukum, RajaGrafindo Persada, Jakarta, p. 41, 2013

[15] Salim HS. Dan Erlies Septiana Nurbani , Penerapan Teori Hukum Pada Penelitian Tesis Dan Disertasi, RajaGrafindo Persada, Jakarta, p. 11, 2013

[16] Ibid.

[17] Soerjono Soekanto, dan Sri Mamudji, Penelitian Hukum Normatif Suatu Tinjauan Singkat, Rajawali Pers, Jakarta, p. 15, 1990

[18] Enrico Simanjuntak, Esensi Sengketa Administrasi Pertanahan Di Peradilan Tata Usaha Negara, Jurnal Bhumi, Vol. 3 No. 2, p. 172, 2017

[19] Nasrun Hipan, Nirwan Moh Nur, dan Hardianto Djanggih, Problematika Penyelesaian Sengketa Tanah Di Lokasi Tanjung Sari Kabupaten Bangai, Jurnal Law Reform, Vol. 14, No. 2, p. 206, 2018

[20] Pasal 24 ayat (1) dan (2) Undang-Undang Dasar 1945.

[21] Undang-Undang Republik Indonesia Nomor 48 Tahun 2009 Tentang Kekuasaan Kehakiman, Pasal 27 ayat (1)

[22] Undang-Undang Republik Indonesia Nomor 21 Tahun 1964 Tentang Pengadilan Landreform, Pasal 2

[23] Undang-Undang Republik Indonesia Nomor 37 Tahun 2008 Tentang Ombudsman Republik Indonesia, Pasal 1 angka (3)

[24] Nurjannah, Undang-Undang Pokok Agraria (UUPA) Sebagai Induk Landreform, Jurnal Al-Daulah, Vol. 3, No. 2, p. 195, 2014

[25] Undang-Undang Republik Indonesia Nomor 21 Tahun 1964 Tentang Pengadilan Landreform, Pasal 8 ayat (1)

[26] Op.cit., Pasal 2

[27] Undang-Undang Republik Indonesia Nomor 7 Tahun 1970 Tentang Penghapusan Pengadilan Landreform, Konsideran huruf a

[28] Op.cit., Konsideran huruf b

[29] Op.cit., Konsideran huruf c

[30] Howard J. Tigris, Kebijakan Dan Pelaksanaan Landreform Di Era Pemerintahan Jokowi-JK, Jurnal RechtsVinding, pp. 2-3, 2016

[31] Mudjiono, Alternatif Penyelesaian Sengketa Pertanahan Di Indonesia Melalui Revitalisasi Fungsi Badan Peradilan, Jurnal Hukum, Vol. 14, No. 3, p. 471, 2007 